\title{
Positioning of Environmental Art Teaching Talents for Industry Needs
}

\author{
Shi Shaomeng \\ Jilin Engineering Normal University,Chnia,130500
}

\begin{abstract}
Design continues to improve people's quality of life and improve people's living environment. Design has penetrated into every aspect of our lives, from a small logo to a city's planning. Design has a close relationship with the society and has attracted more and more people's attention. The ultimate goal of design is to cultivate applied design talents for the society, who can meet social needs, meet people's needs, and have innovative spirit and practical ability. Faced with the competition of the market and the requirements of corporate enterprises for applied art design talents, environmental art design education should strengthen practical teaching, so that the students who train the students can apply what they have learned and use them to adapt to the development needs of the times and society.
\end{abstract}

\section{INTRODUCTION}

In recent years, the environmental art design profession has been developing rapidly in China. Different institutions of higher learning have started to add environmental art design majors. There are two main reasons for this: First, the market demand for this specialty is relatively large, and the employment situation is good. . Second, the profession itself is a highly skilled profession. They have the characteristics of practicality, skill and skill, and adapt to the social ability. Therefore, the profession set in the school is very popular. In this system, trained professionals continue to flock to the society, improving the employment level of the industry, and meeting the balance of social supply and demand, but at the same time there are such problems.

For example: 1. There is no uniform standard for the syllabus implemented by various institutions, and some still use the "Art Syllabus" promulgated by the former Ministry of Education, and it is subject to the study of painting subjects. It led to the teaching of environmental art design under the inertia of "art" education. The interior design teaching stayed in the empty "formalism" and the so-called "decorativeism". Others often refer to the training mode and curriculum of professional art colleges. The curriculum is too close and lacks personality. 2. Some professional curriculums lack research and profound understanding of the essential characteristics of applied talents, lack of the age and pertinence of social occupations, and most importantly, there is a certain gap between social application and practical needs, and the curriculum system It does not meet the goal of application-oriented talent education, and students cannot graduate to meet the needs of social occupation. 3. Although some courses have the synchronization of the times, the professional teaching mode and content are too old, the professional settings are too narrow, the teaching methods are single, and the practical skills are insufficient. There are often 'teaching in the classroom', 'learning on the blackboard' The drawbacks of driving, environmental art design students will eventually face the market and enter the society, and many students are often used to design behind closed doors, which are out of touch with the market, lack of practicality and derailment from society. 4. The target orientation and characteristics of the newly-built local general undergraduate colleges are not clear. 5. The investment in teaching conditions is seriously insufficient. Students have limited access to high-tech equipment, and their practical ability is not strong enough to adapt to modern design needs. The growth rate of social demand for environmental art talents is as follows. 


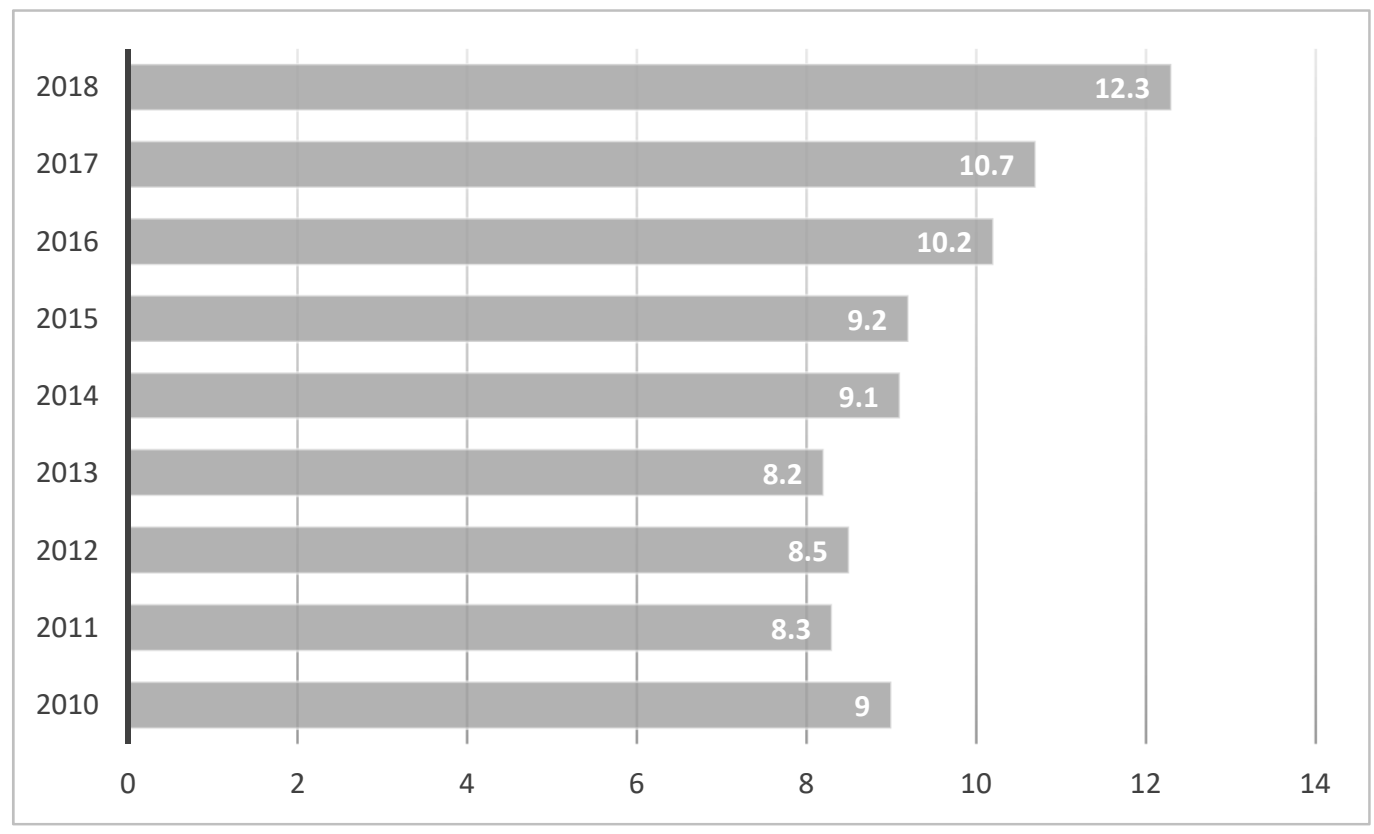

Figure 1: Growth rate of social demand for environmental art talents.

Judging from the goal of talent training and the actual needs of society, the current high art design education in China is mainly composed of professional art colleges, comprehensive universities, normal universities and related art design institutes of engineering colleges. They are training higher level. There are obvious advantages in the professional talents who have good artistic quality and cultural heritage and have a solid knowledge of design theory. However, with the development needs of the society, the training requirements for talents are targeted, and the market demand for design talents is full. Azimuth and multi-level, talents with only the above conditions are far from enough. In fact, enterprises and markets are also eager to have a large number of high-level comprehensive qualities, not only master certain theoretical knowledge, but also have strong creative design capabilities; Familiar with specific job skills and application-oriented professional design talents. In the job interview, employers often virtualize into a client with specific needs, and examine your ability to deal with problems and solve problems. The design level is only Seeing as part of the ability, that is, the employer not only requires you to examine your Design capabilities and levels, as well as your comprehensive capabilities, including design, materials, processes, budgets, technical experience, etc. In this era, whether from the trend of the discipline itself or from social development In terms of the requirements of design education, the narrower and single closed education model of art design education can not meet the needs of the development of the times, and build a "cultivating practical and applied innovative design talents with innovation as the core". An efficient and open modern art design education model is necessary. Therefore, it is necessary for the art design circle art education to conduct targeted research and reform classroom teaching for professional practical teaching, which is the prerequisite for realizing the practical teaching of the ring art design profession[1].

\section{THE IMPORTANCE OF PRACTICAL TEACHING IN ENVIRONMENTAL ART DESIGN}

Environmental art design belongs to the category of practical art. It integrates art and craftsmanship. It requires designers to have both artistic aesthetics and superb manual skills. Nowadays, the era has given a new concept to environmental art design. It fully reflects the aesthetics of people in the modern living environment, involving economics, social culture, consumer psychology, etc., and the evolution of such a form, content Constantly expanding and constantly updating the market demand, only by constantly updating the teaching, increasing the intensity of practical teaching, ensuring that the environmental art design education is in line with the society, adapting to the needs of the space environment in the new era, can cultivate an excellent application-oriented art with innovative consciousness[2]. Design talent. At present, in the practical teaching of most art colleges and universities, the practical teaching of design art should be based on the content and form of practical teaching, standardize the teaching, pay attention to the application ability of students design, and enhance the social competitiveness of students. Form the professional teaching characteristics of the school and highlight the teaching characteristics of the application-oriented design talents.

The essence of practical teaching of environmental art design is the combination of theory and practice. The essence of the practical teaching of design art is first reflected in the combination of design theory and design practice. Comrade Mao Zedong once said that understanding has gained theoretical understanding from practice and practice, and the theory must return to practice to guide practice. The theory comes from practice and guides practice. Grasping the regularity of the world, we must put it back into the practice of 
transforming the world. This theory is very applicable in the design of practical courses in the design of art.

\section{IMPLEMENTATION STRATEGIES OF PRACTICAL TEACHING MODE IN ENVIRONMENTAL ART DESIGN MAJOR}

How can we implement the practical teaching mode in the design profession? First of all, it is necessary to clarify the practical and applied art design talent training objectives and the guiding ideology for running a school. It is to cultivate the urgently needed, innovative and income-generating ability for the society and local enterprises. Design talent. Therefore, we must adhere to the open school, the combination of teaching and social practice, and emphasize the innovation in education, that is, the renewal of educational concepts, including the innovation of teaching methods and specific methods. The core of this is to create a deep art design major. The comprehensive quality of quality and solid artistic practice and application ability, cultivate innovative and creative income-generating applied art design talents, and thus build a perfect practical teaching core system[3].

Constructing a practical teaching system is a key part of highlighting the characteristics of the training mode of innovative artistic design talents, which also ensures the goal of talent training and the quality of personnel training. The specific envisages are as follows.

\subsection{INCREASE THE CLASS TIME RATIO OF PRACTICAL COURSES}

The students' practical ability and the ability of hands-on ability depend to a large extent on the degree of study and emphasis on practical courses, while focusing on increasing the proportion of practical courses and practical teaching content in teaching design and curriculum. It can play an important role in the protection of this ability objectively. The art design profession itself has strong practical characteristics. Therefore, in the arrangement of the course content, in addition to mainly training the relevant competency elements required for the profession, it is also necessary to take into account or refer to the specific requirements of relevant industries and related posts. To effectively strengthen the cultivation of students' practical ability and practical ability[4]. The class time calculation can be performed by the following formula. Where $r_{i}$ represents the duration of the course, $\sigma_{i}$ represents the total duration, $\rho$ represents the statistical function, and $J$ represents the class time ratio.

$$
J=\sum_{i=1}^{m} \rho\left(\frac{r_{i}}{\sigma_{i}}\right)
$$

\subsection{FOCUS ON THE PRACTICALITY OF THE TEACHING PROCESS}

While paying attention to the practicality of teaching content, pay attention to the practicality of the teaching process, pay attention to the connection between the various practical teaching links, especially in the teaching process of basic skills and professional skills courses, as long as the conditions permit, students should be required to do specific Exercising a kind of physical object (work or product), training students to experience and master their corresponding knowledge and skills through the process of production. As for the special design course, students should be required to understand and understand through the specific practice of the whole process. Master the specific requirements of each link, and master each individual skill and comprehensive skills.

\subsection{STRENGTHENING THE PRACTICAL CONNOTATION OF THE TEACHING PROCESS WITH REAL TOPICS}

It is undoubtedly the most ideal choice to arrange real-life projects and real-life projects in relevant courses, and organize and arrange teaching with specific design projects entrusted by enterprises. It can greatly strengthen the practical connotation of the teaching process, train students to experience and participate in the whole process of the subject, so that the training, knowledge and skills acquired by the students are undoubtedly all-round.

\subsection{IMPROVE THE INTERNAL AND EXTERNAL TRAINING BASES REQUIRED FOR PRACTICAL TEACHING}

The construction of a practical teaching base is undoubted for the role of strengthening practical teaching and cultivating students' practical ability and hands-on application ability. The construction of the on-campus training room, due to the development needs of the professional, fully consider its practicality and rationality, and should fully pay attention to its advanced nature and room for development, and should also select a group of well-known decorative companies in the relevant collections. As an off-campus training base, students will have the opportunity to directly face customers, understand the market demand, and design the "real knife and gun", which will be their professional quality of art design, practical application ability, interpersonal communication ability and The ability to work together has a positive impact.

\section{Conclusions}

In short, the cultivation of applied art design talents, the positioning of the target, the requirements of the market and the talents of the enterprise and the professional characteristics of the art design determine that the art design education must construct a complete set of practical teaching system. In order to cultivate new design talents with strong practical ability and strong hands-on ability, only by realizing the importance of the practical teaching mode can we truly achieve the 
three-in-one combination of "teaching, learning, and doing", so that we can truly build on the "professional quality, strong hands-on ability, and the ability to stay, to stay., well-used application art design talents.

\section{References}

1. Xiangdong Dou. Application of Question Teaching Method in the Art and Design Teaching of Universities[J]. Open Journal of Social Sciences,2015,03(11).

2. Yan Yang. Teaching Research on Higher Vocational Pre-School Education of Professional Art Course Based on Innovation and Entrepreneurship Education[J]. Creative Education,2018,09(05).

3. Xiaochuan ZHANG,Bin JIANG. Research on the Scientific Research Evaluation Innovation System of Humanities and Social Sciences in Research I Universities under the New Situation[J]. Canadian Social Science,2017,13(4).

4. Dale C. Hesdorffer,Michael Trimble. Musical and poetic creativity and epilepsy[J]. Epilepsy \&amp; Behavior,2016,57.

5. Sara E. Mazzoni,Sarah E. Brewer,Jennifer L. Pyrzanowski,M. Josh Durfee,L. Miriam Dickinson,Juliana G. Barnard,Amanda F. Dempsey,Sean T. O'Leary. Effect of a multi-modal intervention on immunization rates in obstetrics and gynecology clinics $[\mathrm{J}]$. American Journal of Obstetrics and Gynecology,2016,214(5). 